\title{
Application of Chemical Grouting as an Option of Removing Soil Moisture - a Case Study in the Reconstruction of the Church
}

\author{
Jana Katunská, Dušan Katunský \\ Technical University of Košice \\ Faculty of Civil Engineering, Institute of Architectural Engineering \\ e-mail: jana.katunska@tuke.sk, dusan.katunsky@tuke.sk
}

\begin{abstract}
The article provides an analysis of removing moisture from the soil masonry walls. The chemical pressure insulation may be considered as one of the alternatives. This paper describes the chemical waterproofing and points to a case study, which is a small church in the town of Košice. Renovation of the church took place in two stages, made using pressure chemical insulation for chemical grouting of envelope masonry. The appropriateness and effectiveness of the applied chemical methods can be seen in the conclusions of this contribution.
\end{abstract}

Key words: ground moisture, moisture proofing, chemical grouting masonry, restoration of historical masonry

\section{Introduction}

Sacral buildings are valuable monuments in the construction of an unavoidable historical and cultural value. In the case of the rehabilitation of moisture such buildings therefore pay more than in other cases it is necessary to carry out construction and technical research and use it to propose a suitable solution to the problem of moisture of building structures. It is necessary to carefully consider all building interventions in moisture damaged structures, to avoid any erratic application of newer technology and is not caused other disorders. Address remediation of moisture building usually consists of several measures. The aim of this paper is to describe possible solutions to the restoration of damp masonry small Roman Catholic church and their subsequent implementation.

\section{Chemical grouting masonry}

\subsection{Types of injection chemical grouting methods}

Types of injection chemical grouting methods can be divided according to the manner of performance the injection wells for pressure and non-pressure grouting. [1] 
Waterproofing curtain wall: sealed with a water-repellent or just plastered masonry structure, by one or more modes of elements throughout the thickness and length of a particular design.

Chemical waterproofing aperture formed in the wall pressure injection of iris created by impregnation of masonry structures by chemical means that a system of pipes and hoses pumped under pressure into the perforated pipes in boreholes stored in the masonry; of these tubes chemical agents wetted inner surfaces of the wells; pressure grouting can be done after certain time intervals (injection pulse) [2], [3]

Injection and infusion means: solutions and dispersions silicate and silicone water-based or solvent, the material sealing and surface properties, and often a fungicidal action, dispersions, emulsions and solutions of some other polymer substances, asphalt emulsion, and wax melt.
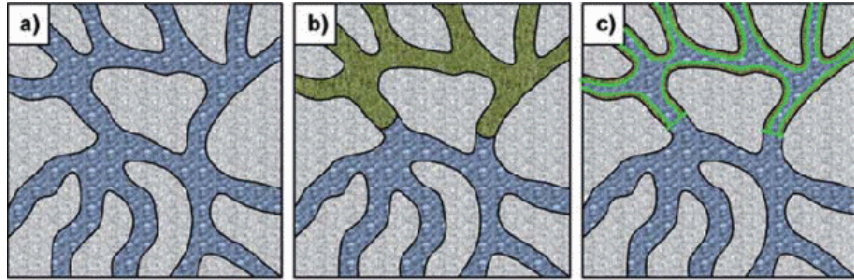

a) material without injection of a solution of it - the pores are filled with water,

b) pore-sealing - inject able solution penetrates into the pores of the masonry that after chemical reaction and hardening into an insoluble state completely fills,

c) the constriction of pores - inject able solution penetrates into the pores of each wall to the chemical reactions and hang narrowed portion of capillary water remains in the pores,

d) the pore walls of the hydrophobic treatment

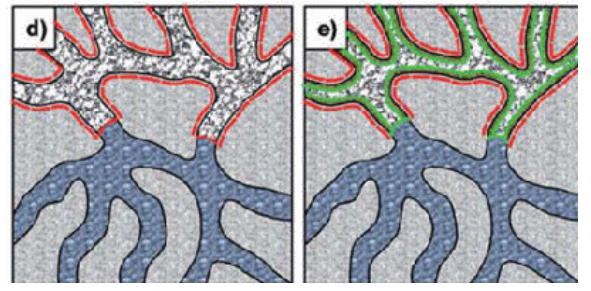

- inject able solution penetrates into the pores much smaller, and of a casing hydrophobic zed thereby reducing or completely prevents capillarity,. water-repellent pore structure remains unchanged and can be after the final date of repenetrate,

e) - a narrow hydrophobic treatment combination of $c$ ) and d)

Figure 1: The basic principles of operation of injection solutions [16]

\subsubsection{Operating principles of infusion and pressure grouting}

More viscous substances are not capable of leaks into the pores of the masonry, and therefore used for the implementation of the pressure opening. Pressure injections are performed in horizontal wells in the priemerre 10 to $12 \mathrm{~mm}$ at a distance of $20-30 \mathrm{~cm}$ apart. The probe must be installed in injection valves - the packer to be concluded mortar. The pressure of the injection pump is polyurethane or epoxy resin (s) blowing pressurized to about 250 psi 0.6 MPa masonry. Sealant must be rectified in liquid form, to fill part of the porosity of the spectrum by the expansion of capacity and cause the following foaming. Foam has a closed porosity and is resistant to rising damp and water pressure. [4], [5]

One group of substances infusion is designed to penetrate (penetrate) into the pores of a chemical reaction solidified to form an impermeable and thus close it. We speak the sealing grouting. This group may also be included crystallization methods using the mechanism of accretion of crystals. 
Table 1: Classification moisture masonry according to standards 730610 [20, 21], and preliminary review of methods and their applications

\begin{tabular}{|c|c|c|l|}
\hline $\begin{array}{c}\text { moisture } \\
\text { level }\end{array}$ & $\begin{array}{c}\text { Mass } \\
\text { humidity } \\
\text { brickwork \% }\end{array}$ & $\begin{array}{c}\text { The cause and } \\
\text { type of content } \\
-\end{array}$ & $\begin{array}{c}\text { Preliminary application methods } \\
\text { Repair option }\end{array}$ \\
\hline very low & $\mathrm{W}_{\mathrm{h}}<3$ & $\begin{array}{c}\text { Rising moisture } \\
(\%)\end{array}$ & \\
\hline low & $3 \mathrm{~W}_{\mathrm{h}}<5$ & $3 \mathrm{~W}_{\mathrm{r}}<4$ & air screens, special coatings, plaster \\
\hline increased & $5 \mathrm{~W}_{\mathrm{h}}<7,5$ & $4 \mathrm{~W}_{\mathrm{r}}<7,5$ & $\begin{array}{l}\text { insertion of additional waterproofing } \\
\text { membranes, plates, sheets }\end{array}$ \\
\hline high & $7,5 \mathrm{~W}_{\mathrm{h}}<10$ & $7,5 \mathrm{~W}_{\mathrm{r}}<10,5$ & $\begin{array}{l}\text { construction arrangements of house } \\
\text { surroundings, waterproofing, plates, }\end{array}$ \\
\hline very high & $\mathrm{W}_{\mathrm{h}}>10$ & $\mathrm{~W}_{\mathrm{r}}>10,5$ & $\begin{array}{l}\text { restoration, drainage, layout building } \\
\text { works around, }\end{array}$ \\
\hline
\end{tabular}

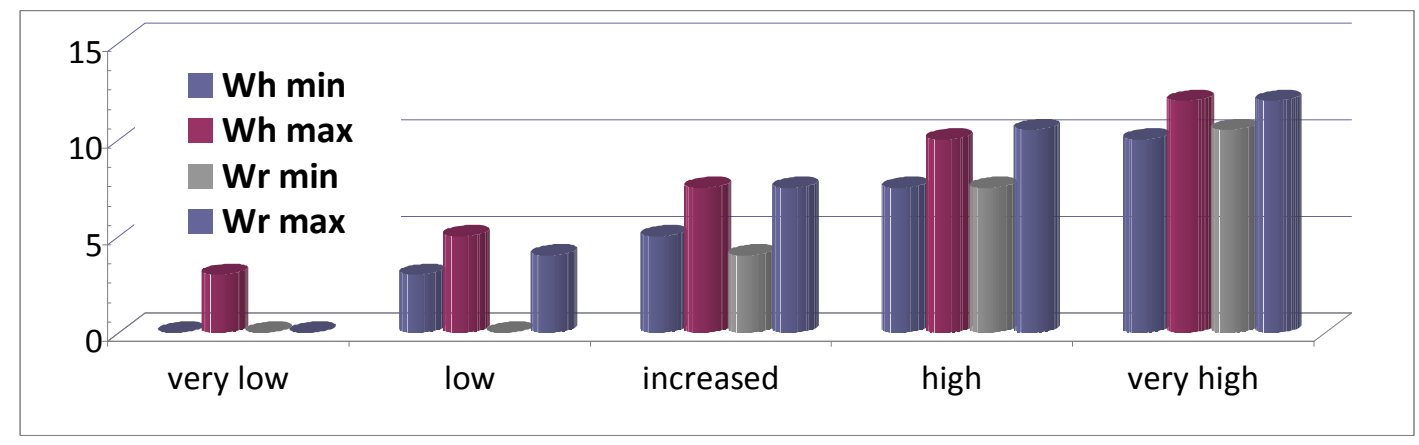

Figure 2: Description of masonry moisture level according to STN and WTA standards

Research in porosity, more specifically, the ability of the pore distribution before and after injection, however, prove to be inadequate filling of the pores in the micro pores, resulting Flaws methods. At present, therefore, it began to apply the method to more hydrophobic pore walls. The infusion material is generally a silicone-based solutions or micro emulsions. The mechanism of action consists in hydrophobic pore walls, which prevents capillarity. These solutions are penetrated into much smaller than the capillaries in the case of the sealing solution having a higher viscosity. The structure of the treated material remains virtually unchanged. After the final date of application it can be repeated. Another group of compounds consists of infusion of mixed formulations of preparation that are created based of the sealing and surface effects. Group these products is very large. [8], [9] 


\subsubsection{Non-pressure grouting - infusion hydrostatic overpressure}

Unpressurised infusions are among the most common and most commonly used applications. Infusion into inclined wells flows through a transport pump using a modified garden or pot. Some technologies associated wells carved grooves in which the outside of the creating of the waterproofing mortar wall and infusion poured into the trough thus formed. This will ensure a uniform level of infusion solutions in all wells. Without pressure infusion it is appropriate to apply low viscosity solutions that easily and penetrate deep enough. Infusions give hydrostatic overpressure making the opening corresponds to a pressure-free method when wells are made in the lower slope. Well heads tubing shall be installed and sealed with mortar. The tubing is connected to the container, which are attached from 0.5 to $2.0 \mathrm{~m}$ from source. It is used paste the difference level solution in the vessel and wellhead. This procedure is suitable for viscous solutions or no ashlar brickwork. The disadvantage is more labor intensive and difficult to seal the tubing. [4], [5]

This type of grouting can be divided by type of non-pressure grouting materials to:

Sealing, hydrophobic, impregnating. [6]

Sealing Grouting agents in the form of porous hydrogel structure of the building material and seal the capillaries. Hydrophobic Grouting agents pore structure achieves water-repellency of building materials, in the case of certain of these compounds there is some sealing effect. After completion of the impregnation, the whole wells filled with grout.

The most abundant group in the market offered by technology commonly used silicon-based materials (silicones, silicates, siliconates, siloxins). Grouting materials produced on the base of gels, and thus clog pores of building materials, or limiting them. They are thus creating a hard material that prevents water penetration (sealing effect). The tapered capillaries can pick up the water, but the possibility of evaporation of water from the masonry is maintained. Further regulates the capillary surface so that water could not be wicked for them because they repel water (The hydrophobic, impregnating effect). [12]

Another group of compounds consists of using products of organic chemistry, in particular the monomers of synthetic resins, either as a single component such as polyurethane (polymerized by the action of moisture), or the two or multi-component, e.g., polyacrylatebased polyurethane. They are applied by pressure injection. Acryl ate gels of high viscosity are suitable for wet, too "salt" of the structure. Maybe those across the board to seal the opposite side of the masonry via boreholes led transversely across the entire wall. Reversibility of the reaction with water allows the humidity can receive and issue. This means that the creation of new micro cracks are able to fill them, thus waterproofing practically never gets old. [13], [14]

\section{Description of the building of the church - case study}

The church is located in a small historic village "Vyšné Opátske", currently the city of Kosice. Church of the Sacred Heart is the only listed building in this village. The church is built on a fairly steep sloping terrain. Sloping area, in which the church is built, is characterized as a landslide with a high water table. From the west side of the church is bordered by Church walkway that lines the edge downward steep slope. From the east side 
close to the church is a public road. From the north to the churches is rising a public road. The south side is a small parking lot completed steep slopes. [7]

The church is from the architectural point of view a simple one-nave sacral building, built early last century in the neo-Romanesque style with elements of classicism. His consecration was in 1912. From a structural point of view, a classic brick building made of solid clay bricks, based on stone foundations. The latest available information on reconstruction is, from the fifties. Then on the southwest side it was erected a small building sacristy and made roof reconstruction. [7]
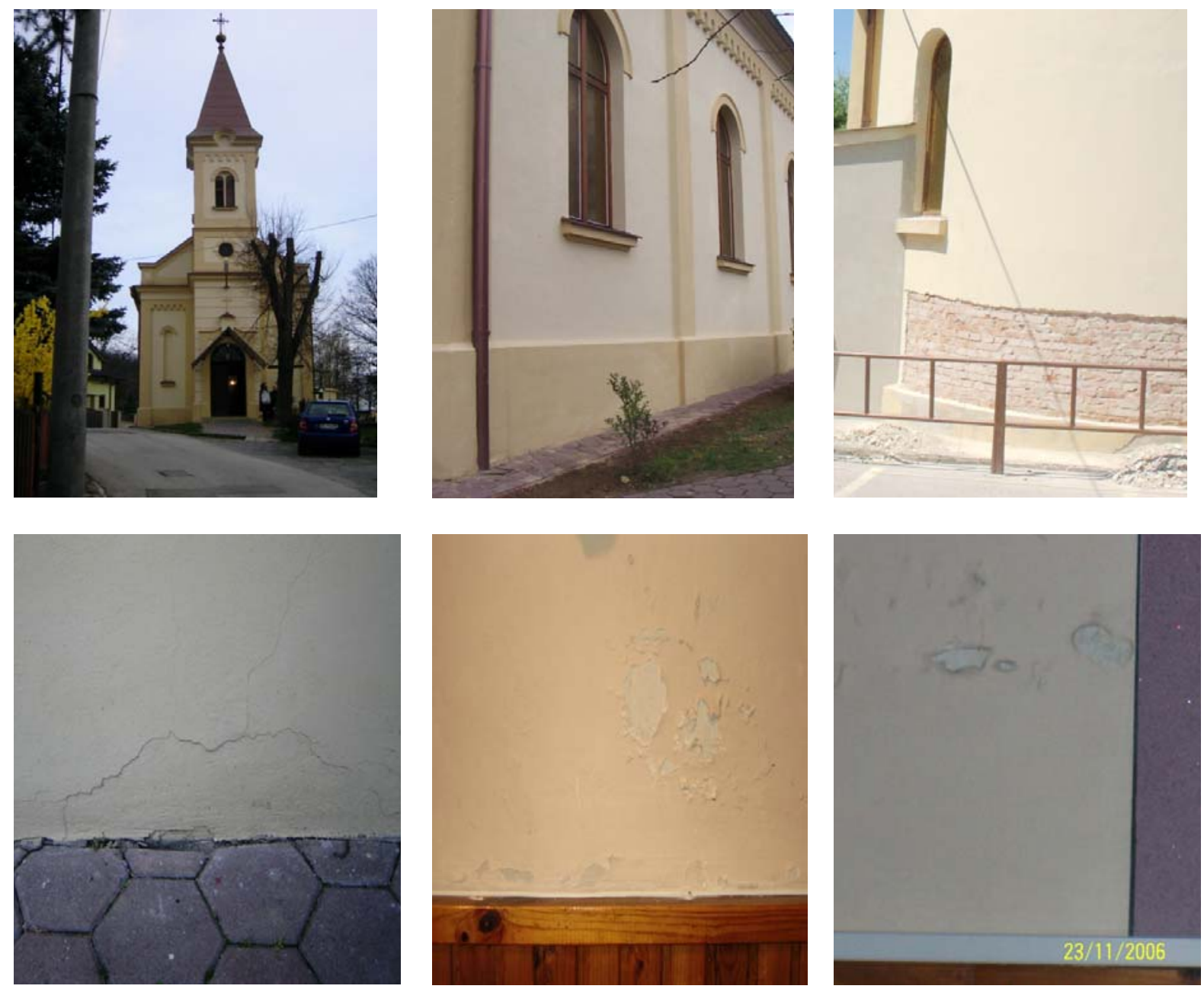

Figure 3: Views of Church "Vyšné Opátske"

Although the church was built on hilly terrain, humidity problems, he did not escape. These are major consequences for interior plaster in the form of damp patches and the subsequent shedding in areas to an increased capillarity of humidity occurred mainly in 50 of the last century, when the natural circulation (evaporation) of water disturbed by improper finishing internal surfaces and oil-based paints followed by building wooden interior wall coverings to a depth of $1 \mathrm{~m}$. 
The situation is getting worse and free draining rainwater roof to the foundation of the church, which was associated with water logging and subsoil of freezing. When building the survey found masonry moisture from the outside, extending to a height of approximately $2 \mathrm{~m}$. On the side of the driving rain was wet masonry along the entire height of the building and the situation deteriorated and leaks from the roof. It has to be seen as color changes, as well as the gradual sloughing plaster surfaces and finishes the section. [7]

\subsection{The moisture survey buildings church}

At the first visual sighting of the church in March 2006 they were also found problems of static character - a crack in the side walls of the church penetrated the entire thickness of outer walls, as well as poorly transferred joints truss renovated in 50 years of the last century. Source analysis of moisture, it was found that the said disturbances are caused by the building from rising damp subsoil and precipitation humidity in through cracks in the wall.

Humidity influences the church:

- Groundwater level, which is in the area is very high; building is not insulated against ground moisture and drainage systems including historical wells are currently inoperative, thereby Ground moisture and groundwater got into direct contact with the foundation structure;

- Steep sloping terrain; soil, which in recent years to build out houses untied, if necessary. The bound around the perimeter walls of the church; Frequent landslides on the site;

- Ineffective drainage system construction roofing, rainfall has been driven by the wind on the wall and the water runs down the surface;

\subsection{Repair design of hydro insulation of church - choosing a suitable methods}

Due to historical culture, architectural, religious and spiritual church building was necessary remediation of moisture masonry perform extremely sensitive. Therefore it eliminates mechanical methods - Undercutting of masonry and driving in sheet that would have been too complicated from a technical point of view (wall thickness, dissected footprint, covering for dual neo-Romanesque arches, etc.). Based on a comprehensive analysis of the following solutions were proposed.

\subsubsection{First phase of renovation}

In the first phase it was necessary ensure the proper drainage of the roof; edit the terrain around the church (to solve max. drain rainwater from the building)

This proposal was implemented in August 2006 together with the total repair external façade.

\subsubsection{Second phase of renovation}

In the second phase it was necessary to repair of interior wall surfaces, restoration plasters to use chemical injection of external walls.

Repair of interior wall surfaces contained tearing down the wooden cladding inside the church, removal of the oil paint on interior wall surfaces and damaged parts of plaster; remediation plaster application; 
Restoration plasters are a suitable method renders the recovery of historic buildings damaged by moisture. The application allows restoration render a better evaporation of moisture from the brickwork and at the same time prevents the formation of undesirable efflorescence. At the church, the survey found a low level of salinity of exterior walls, which increases the life of restoration remain.

Chemical injection of external walls is the shield waterproofing method. The essence of the injection, i.e. barriers with a chemical mass is injected into the pre-drilled holes in moist masonry. Grout in boreholes reacts and that creates a chemical process called. Waterproofing screen prevents moisture. Grout applies methods infusion (without pressure or hydrostatic pressure) or pressure injection. Result of chemical grouting lies in the correct analysis, proper identification of the causes wetting properly selected technologies dependent on the use of the injection material. Their specific chemical composition, manufacturers typically do not. [11]

\subsubsection{The procedure chosen grouting masonry church}

Chemical grouting was carried to the church in 2012 with the help of the company "Atro". It was designed and implemented additional horizontal insulation of masonry against moisture injection holes. The opening (bore holes with a diameter of $12 \mathrm{~mm}, 150 \mathrm{~mm}$ ) by the exterior of the infusion concentrate was applied Kiesel Inject cream (concentrate for silicified very low viscosity based on special silicates, hydrophobic ingredient).
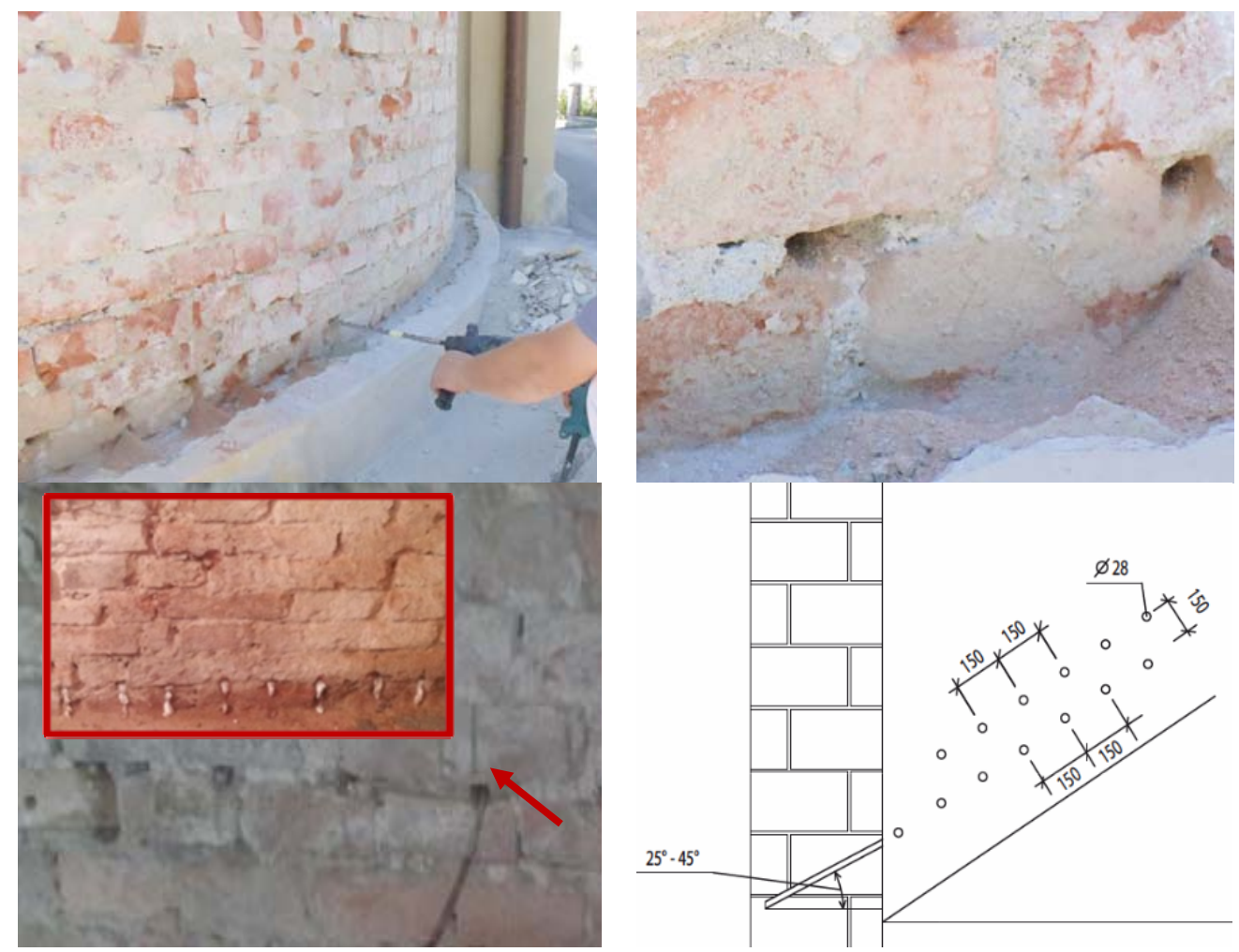

Figure 4: The basic principles of chemical injection of external walls of injection solutions in external walls of the church Vyšné Opátske 


\subsection{Discussion}

Classification of moisture masonry according to table 1 is sufficient for common practice, but in terms of usability of the injection method is inadequate. In particular, it is inappropriate assessment by percent weight moisture, because the alleged failure to inform injectibility masonry. The moisture content of the masonry, where the majority of pores filled with water, and the injection solution of the material does not get into the structure and cannot be injected, such masonry. This lack of realized Directive WTA 4-4-96 authors who Directive introduced the term "degree of wet, assesses the content of moisture in the masonry due to its porosity. This means that in addition to the moisture content in percent by weight is necessary to provide each and the open porosity of the material [14].

The degree of wet $S p$ is defined by:

$$
S p=\frac{\left(W_{h}\right) \times 100}{P_{0}}[\%]
$$

$W_{h}$ - mass material moisture [\%],

$P_{o}$ - open porosity of the material, equal to the maximum absorbency of the material weight. $[\%]$.

Without pressure injection may be used up to the dampness of about $50 \%$ for pressure injection is referred to an upper limit of about $80 \%$ [18].

According to Table 1, the moisture in the masonry both cases classified as high, but as seen in the differences degree of wet, using the injection methods, the solution got much easier in the wall 1 . This example is illustrative; in practice it would be necessary to consider a used binder other impacts [18].

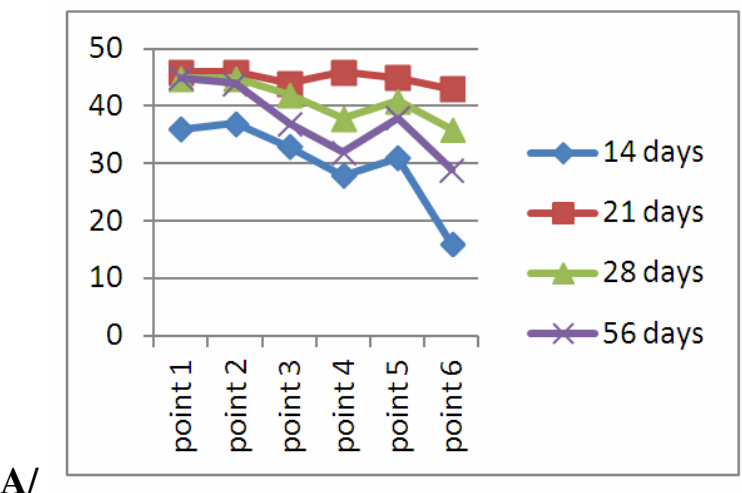

A/ before insulation

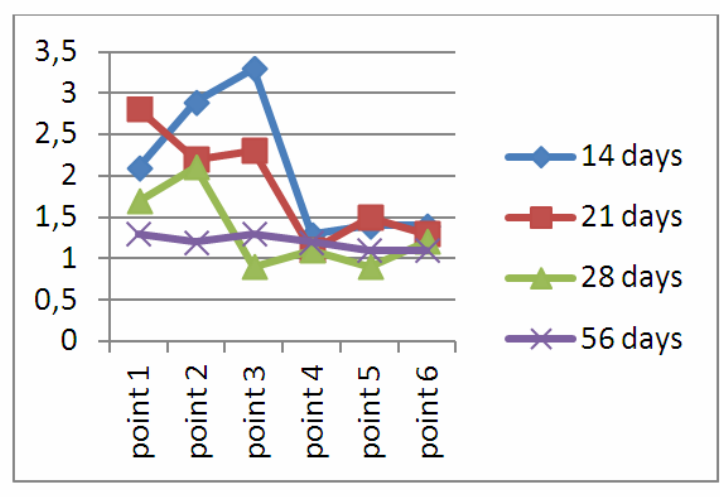

$B$ / after the application of chemical damp

Figure 5: An example of reducing the moisture content of the application of chemical insulation in the masonry of aerated concrete - according [8]

All rules for use of chemical grouting can be applied in compliance with regulations. See standards and regulations 15$]$. 


\section{Conclusion}

Protection of buildings against water and moisture is one of the important measures in terms of security of their life and functional capacity. The moisture regime of the Church of the Divine Heart adversely affected by a number of inappropriate interventions that in the past worsened and threatened status of its masonry structures. Implemented technical measures (landscaping, roof drainage into storm sewers) reduced moisture load external walls of the church. Designed and implemented a method of rehabilitation of humid masonry chemical injection prevents the infiltration of ground moisture into external walls of the church building.

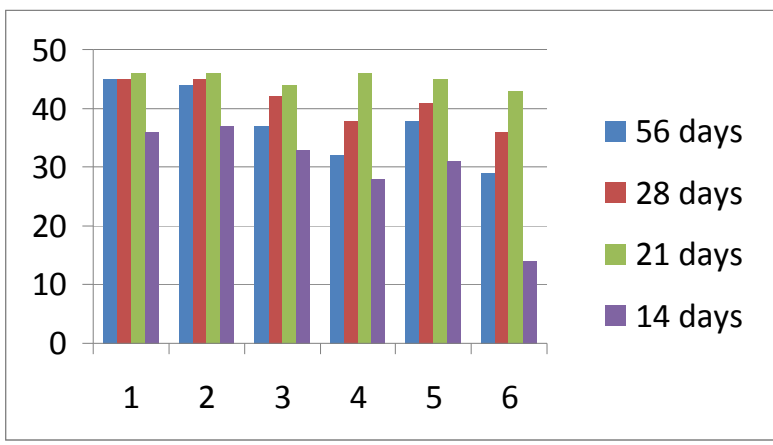

\section{A/ before insulation}

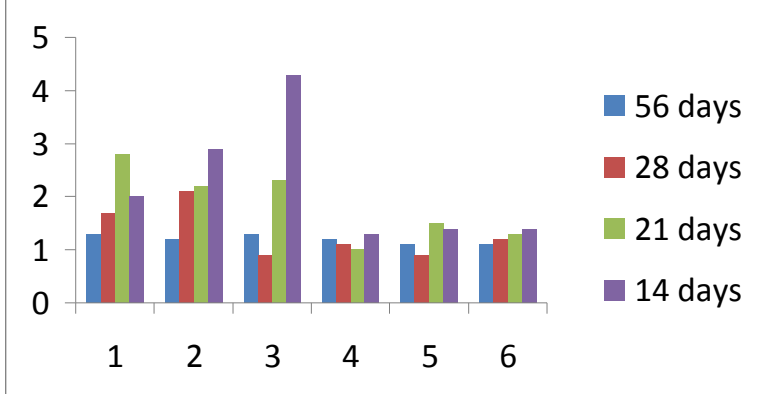

$B$ / after the application of chemical grouting

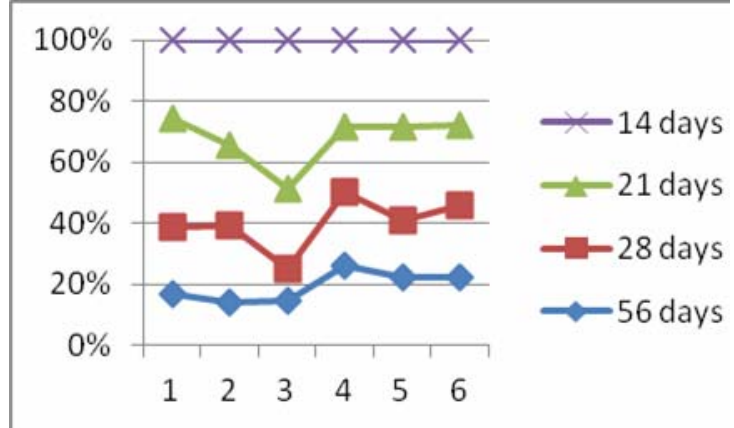

C/ Comparison to the situation after 14 days moisture content

Figure 6: Reduction of moisture content

The percentage of volume moisture after evaporation in the samples - the reduction of moisture content expressed in percentage compared to the situation after 14 days (designated as the basis of 100\%) A before and $\mathrm{B}$ after the application of chemical grouting

The masonry formed gel-like insulating layer assists in the drying of walls, which enhances the natural movement of moisture from the structure. Then gradual mineralization strengthens additionally treated material building element (material). Kiesel product contains no solvents and therefore not released to the atmosphere and no harmful fumes. The proposed remediation procedure and fully respects the importance of this cultural monument.

\section{Acknowledgements}

This paper was created thanks to the financial support from research project no. 1/0835/14 of Slovak Scientific Grant Agency (VEGA) in collaboration with Slovak Ministry of Education, Science, Research and Sports and Slovak Academy of Sciences. 


\section{References}

[1] Semerák, P. (1998). Methods for measuring moisture building materials, Prague, STOP

[2] Lipták, T. (1988). Additional removal of moisture from the walls, Bratislava, ALFA

[3] Weber, H. (1988). Mauerfeuchtigkeit, Ursachen and Gegenmassnahmen, Renningen, Expert Verlag

[4] Weber, H. (1999). Moisture walls and the removal of I. and II. In: Construction materials, Vol. 5, No. 5, p. 78-80.

[5] Katunská, J. (2013). Sanačné opatrenia vlhkého muriva kostola, dodatočná hydroizolácia injektážou. In: Střechy, fasády, izolace. Vol. 20, No. 11-12, p. 40-42. - ISSN 1212-0111

[6] Katunský, D. Zozulák, M. Vertal', M. Kondáš, K. Baláž, R. (2013). Measuring Methodology and Results of Heat-Air-Moisture Performances at Building Envelope Levels", Advanced Materials Research, Vol. 649, pp. 85-88, DOI: 10.4028/www.scientific.net/AMR.649.85

[7] Katunská, J. Katunský, D. (2008). Diagnostic of Selected Industrial Building and Design for its Thermal Refurbishment, Selected Scientific Papares- Journal of Civil Engineering, Vol. 3, Issue 1 , pg. 9

[8] A. Struhárová, (2014). Chemical grouting method and its effectiveness for protection of autoclaved aerated concrete masonry, Advanced Materials Research, Vol. 923, pg. 112-116, DOI: 10.4028/www.scientific.net/AMR.923.112

[9] Hejtmánek, M. (2010). The rehabilitation of wet masonry, In: Conference "Bardkontakt 2010 Problems of Urban Heritage Centers", 24-25. august 2010, Bardejov

[10] Katunská, J. Katunský, D. (2002). Evaluation of the Quality of the Internal Microclimate in Large Industrial Halls / Bewertung der Qualität des inneren Mikroklimas in großen Industriehallen, International Journal for Restoration of Buildings and Monuments, Internationale Zeitschrift fur Bauinstantsetzen und Denkmalpflege, Vol. 8, Issue 4, pg. 371-378, DOI: $10.1515 / \mathrm{rbm}-2002-5681$

[11] Vašková, A., Korjenic, A., Katunský D.: Kirchenheizung und Veränderte Rauklima nach der Renovierung einer Kirche - Fallstudie. In: Poruchy a obnova obalových konštrukcii budov 2013 : zbornik z konferencie medzinárodnou účastou : 3. - 5. april 2013, Podbanské, Vysoké Tatry. Košice : TU, 2013 S. 228-235. - ISBN 978-80-553-1393-1>>

[12] Lopušniak, M., Vašková, A.: Výsledky měření vybraných ukazatelů vnitřníhprostředí v budově experimentálního rodinného domu. In: TZB-info. (2012), pg. 1-7. - ISSN 1801-4399 Spôsob pristupu: http://www.tzb-info.cz/:

[13] Vaškovičová, A. [et al.] (2006). Success dehumidification of masonry depended also on correctly diagnostics In: 30. MVKUPS - Brno VUT, pg. 114-120. - ISBN 8021432373

[14] Zozulák, M., Katunský, D. (2015). Numerical and experimental determination of in-structure temperature profiles, Selected Scientific Papares- Journal of Civil Engineering, Vol. 10, Issue 1, pg. 8, DOI: 10.1515/sspjce-2015-0007

[15] Standards and DirectiveS: WTA-CZ, A/ Wall injection against capillary moisture WTA4-4-96, $110 \mathrm{pg} \mathrm{B/Additional} \mathrm{insulation} \mathrm{in} \mathrm{structures} \mathrm{in} \mathrm{contact} \mathrm{with} \mathrm{the} \mathrm{ground;} \mathrm{WTA-4-6-03} \mathrm{/} \mathrm{D,}$ WTA-CZ Praguen Directive WTA Injection masonry against rising damp WTA 4-4-04 / D, WTA-CZ Praguen Standard CSN 730610 P, (2000). Waterproofing masonry, restoration of damp buildings, under the regulations, Waterproofing of buildings - Moist masonry General Provisions. CSN 73 0610, Prague 